\title{
Sedimentological and Rheological Properties of the Water- Solid Bed Interface in the Weser and Ems Estuaries, North Sea, Germany: Implications for Fluid Mud Classification
}

\author{
Svenja Papenmeier ${ }^{\dagger}$, Kerstin Schrottke ${ }^{\dagger}$, Alexander Bartholomä \\ Flemming \\ "Institute of Geosciences \& Cluster of Excellence \\ "The Future Ocean," at Kiel University \\ Otto-Hahn Platz 1, 24118 Kiel \\ Germany \\ "Senckenberg Institute \\ Department of Marine Research \\ Suedstrand 40, 26382 Wilhelmshaven \\ Germany
}

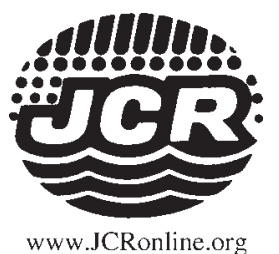

www.JCRonline.org

\begin{abstract}
Papenmeier, S.; Schrottke, K.; Bartholomä, A. and Flemming, B.W., 0000. Sedimentological and rheological properties of the water-solid bed interface in the Weser and Ems estuaries, North Sea, Germany: implications for fluid mud classification. Journal of Coastal Research, 00(0), 000-000. Coconut Creek (Florida), ISSN 0749-0208.

Fine, cohesive sediment suspensions are a common feature of estuarine environments. Generally, multilayer models are used to describe the vertical distribution of such sediments. Such conceptional models normally distinguish at least high suspended sediment concentrations (SSCs) as a topmost layer and a consolidated bed layer, often including an intermediate, fluid mud layer. Rheological, and in particular sedimentological properties are rarely included in these models. New data from two different estuaries provide new insights that can contribute toward the classification of nearbed cohesive sediments.

The water-solid bed interfaces within the turbidity maximum zones of the Weser and Ems estuaries were sampled with 2-4-m-long cores. At 10-cm intervals, values of SSC, viscosity, particulate organic matter, mud: sand ratio, temperature, salinity, and grain-size distributions were determined. By normalizing these parameters to SSC and performing a cluster analysis, sediment suspensions of $<20 \mathrm{~g} / \mathrm{L} \mathrm{SSC}$, fluid mud with up to $500 \mathrm{~g} / \mathrm{L}$ SSC, and an underlying cohesive/consolidated bed can each clearly be distinguished. However, changes in flow behaviour and sedimentological characteristics represented by a shift in the cluster grouping support a subdivision of the fluid mud into a low-viscosity (I) (20-200 g/L SSC) and a high-viscosity (II) (200-500 g/L SSC) layer. Furthermore, by normalizing SSC measurements, site-specific differences were observed in the rheological behaviour of the fluid mud which might be caused by differences in grain-size composition. This suggests that the widely accepted 3-layer model of vertical SSC profiles should be extended by two layers of fluid mud identified in this study.
\end{abstract}

ADDITIONAL INDEX WORDS: Cohesive sediments, Rumohr-type gravity corer, viscosity, grain size, cluster analysis.

\section{INTRODUCTION}

High suspended sediment concentrations (SSCs) of fine, cohesive material are characteristic for tidal estuaries, especially in the turbidity maximum zones (TMZs). The amount and spatial distribution of this suspended particulate matter (SPM) depend on river runoff, tidal forcing, and marine and fluvial sediment supply. Generally, SSCs in microtidal estuaries reach values around $0.1-0.2 \mathrm{mg} / \mathrm{L}$, as opposed to macrotidal estuaries, where SSCs typically reach values of 1-10 g/L (Brown et al., 2006).

Vertical distributions of SSC and SPM density in the water column and the underlying bed are often described using twoor three-layer models (e.g., Nichols, 1984). Two-layer models represent particle-by-particle settling from dilute suspensions onto a previously settled mud bed under zero horizontal and vertical flow. In those cases, density profiles indicate a

DOI: 10.2112/JCOASTRES-D-11-00144.1 received 24 July 2011; accepted in revision 10 December 2011.

Published Pre-print online 30 November 2012.

(c) Coastal Education \& Research Foundation 2012 discontinuity at the water-bed interface (Nichols, 1984). Three-layer models are more frequently used in higher energetic environments where an additional intermediate layer consisting of a denser suspension is distinguished (Nichols, 1984). The classification and terminology of the constituent layers vary in the literature. The upper layer in the three-layer models is often termed low to highly concentrated suspension (Winterwerp and van Kesteren, 2004) or mobile suspension (Ross, Lin, and Mehta, 1987; Ross and Mehta, 1989; Uncles, Stephens, and Harris, 2006). In this fluid-supported layer, particles settle freely in SSCs of a few milligrams to grams per liter (Ross, Lin, and Mehta, 1987). The concentrated suspensions behave like a Newtonian fluid (Wurpts, 2005). Initially, as SSC increases with water depth, the settling velocity increases because of Brownian motion (Uncles, Stephens, and Law, 2006). This condition changes at higher SSCs, where settling velocities are slowed because of the effects of hindered settling (Dankers and Winterwerp, 2007).

The onset of hindered settling is often associated with the appearance of a lutocline (Kineke and Sternberg, 1995; Mehta, 1991; Nichols, 1984; Ross and Mehta, 1989; Ross, Lin, and 
Table 1. Source literature for upper and lower fluid mud boundary SSC by different authors.

\begin{tabular}{lcc}
\hline \hline Author(s) & $\begin{array}{c}\text { Upper Fluid Mud } \\
\text { Boundary (g/L) }\end{array}$ & $\begin{array}{c}\text { Lower Fluid Mud } \\
\text { Boundary (g/L) }\end{array}$ \\
\hline $\begin{array}{l}\text { Inglis and Allen } \\
\quad(1957)\end{array}$ & 10 & 480 \\
Krone (1962) & 10 & 170 \\
Sylvester and Ware & 4 & 400 \\
$\quad(1976)$ & 50 & 480 \\
Wells (1983) & 3 & 320 \\
Nichols (1984) & 10 & 480 \\
Faas (1984) & 200 & 400 \\
Kendrick and $\quad$ Derbyshire (1985) & 10 & several 100 \\
Winterwerp and van & & \\
$\quad$ Kesteren (2004) & & \\
\hline
\end{tabular}

Mehta, 1987; Smith and Kirby, 1989). Lutoclines represent the upper boundary of the intermediate layer or the so-called fluid mud. The SSC values at which lutoclines occur, as described in the literature, are summarized in Table 1 . A widely reported and generally accepted SSC value is $10 \mathrm{~g} / \mathrm{L}$ (Kineke and Sternberg, 1995; Kirby, 1988; Manning, Langston, and Jonas, 2010; Ross and Mehta, 1989; Wells and Coleman, 1981). In general, fluid mud is a mixture of water, clay, silt, and particulate organic matter (POM) (McAnally et al., 2007). In more energetic environments, very fine and fine sands are sometimes additional constituents (McAnally et al., 2007). At higher fluid mud concentrations, downward settling of particles is inhibited by upward escaping fluid and the progressive development of a particle-supported framework structure (Kineke and Sternberg, 1995; Nichols, 1984). In addition, the flow behaviour becomes non-Newtonian (Manning, Langston, and Jonas, 2010; McAnally et al., 2007). However, vertical and horizontal particle movement is still possible (Kirby, 1988; Mehta, 1991). The lower fluid-mud boundary is generally specified by the level at which the horizontal flow velocity becomes zero (Mehta, 1991; Ross and Mehta, 1989). In the literature, SSC values at this boundary vary between some hundreds of grams per liter ( $c f$. Table 1).

In most studies, the description of suspended sediments is based on a rather limited number of parameters, such as SSC, SPM density, and current velocity. However, additional properties have been shown to be important (e.g., Faas, 1984). Among those are properties reflecting the shear behaviour of the fluid flow, such as the relationships among SSC, shear rate, and shear stress, as observed in laboratory-generated mud (e.g., Wright and Krone, 1989). The few field studies on natural fluid mud show that viscosity increases exponentially with increasing SSC (Faas, 1984; Granboulan et al., 1989). In situ measurements by Wells and Coleman (1981) in fluid mud on the continental shelf between the Amazon and the Orinoco rivers yielded values of 0.002-21.0 pascal-seconds $(\mathrm{Pa} \cdot \mathrm{s})$ Again, fluid mud viscosities of up to $15 \mathrm{~Pa} \cdot \mathrm{s}$, measured with a viscosimeter, are known from the Gironde estuary, France, where maximum SSC values reach $600 \mathrm{~g} / \mathrm{L}$ (Granboulan et al., 1989). There, higher values are exclusively linked to brackish and marine sites with higher amounts of suspended silt and sand, such as in freshwater environments with clay-dominated fluid mud.

Changes in the flow behaviour of fluid mud from the NE continental shelf of Brazil are also linked to increasing SSC (Faas, 1984). Fluid mud of lower concentration ( $<300 \mathrm{~g} / \mathrm{L} \mathrm{SSC})$ behaves pseudoplastic, whereas at higher concentrations, a viscosity "notch" appears. At that point, the flow behaviour is dependent on the shear rate. Initially, at low shear rates, fluid mud flow behaviour is pseudoplastic, being related to the rapid breakdown of loose, flocculent particle structures (Faas, 1981). With increasing shear rates, the flow changes to dilatant behaviour, where individual clay particles orientate themselves into a parallel alignment with closer packing, thereby, causing a temporary shear thickening (Faas, 1981). At greater shear rates, the fabric structure breaks down and pseudoplastic behaviour is reestablished (Faas, 1981). The SSC boundary, at which flow behaviour changes, seems to be dependent on the nature of the estuarine environment. Thus, in fluid mud of the NE continental shelf of Brazil, this boundary occurs at around $300 \mathrm{~g} / \mathrm{L}$ (Faas, 1984). Generally, freshly formed fluid mud is weakly consolidated, and as long as its behaviour is pseudoplastic, it can be eroded throughout the range of shear stresses and shear rates that realistically occur in estuarine environments.

Particle size and composition can strongly influence shear behaviour and settling velocity. Mean particle sizes in fluid mud vary substantially, ranging from $<10 \varphi$ (Wells and Coleman, 1981) to 7.9-6 $\varphi$ (Nichols, 1984) and 6.6-4.3 $\varphi$ (Mitchell et al., 2002). The settling velocity of particles increases with size, especially for particle aggregates formed during slack water (Kranck, 1981; Mitchell et al., 2002). Sand within the matrix increases the bounding potential between clay particles (Manning, Langston and Jonas, 2010) and enhances the compaction and densification of the material (Whitehouse et al., 2000). A sand: mud ratio of $50 \mathrm{wt} \%$ can raise the erosional shear stress by a factor of two (Mitchener and Torfs, 1996). In addition, the type of clay controls the cohesiveness of the suspension. Kaolinite is the least cohesive and smectite and montmorillonite are highly cohesive, whereas illite occupies an intermediate position (Mehta, 1989).

Particulate organic matter also plays an essential role in the development of fluid mud, by promoting particle flocculation (Kranck, 1981). Internal friction, and hence the flow behaviour of fluid mud, changes with varying organic content (de Jonge and van den Bergs, 1987). On the one hand, microbial slimes act as lubricants (Wurpts, 2005; Wurpts and Torn, 2005), whereas, on the other hand, POM has a stabilizing effect when polymers produced by biological processes are absorbed onto particle surfaces to form bridges between the particles (van Leussen, 1999). The POM content and composition are controlled by environmental conditions. Light limitation, caused by high turbidity, reduces primary production and, thereby, the amount of organic matter (Herman and Heip, 1999). Changes in temperature, salinity, and nutrients can result in a turnover of species and their distribution (Herman and Heip, 1999). The POM content in fluid mud is highest in quiescent environments (e.g., Lake Okeechobee, Florida: 40 wt\%; Mehta, 1991), whereas values are generally lower in estuaries, deltas, and along highenergy coasts (e.g., the continental shelf between the Amazon 


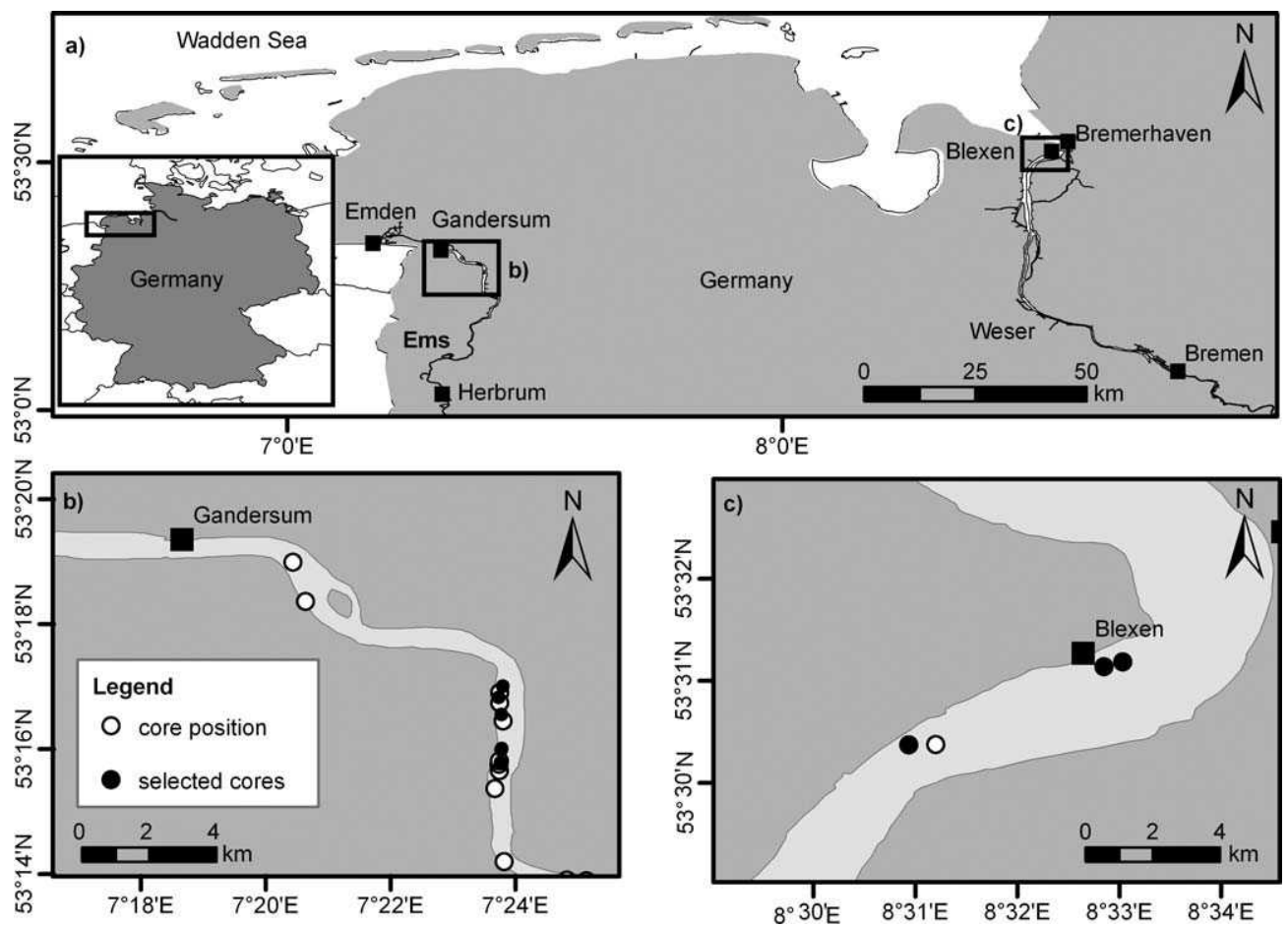

Figure 1. Location of the study areas along the German North Sea coast (a). Detailed charts of the study areas within the Ems (b) and Weser (c) estuaries showing sample positions. Black circles highlight the cores that were used for SSC normalization in Figure 3.

and Orinoco rivers, where POM contents range from 1.52.2 wt\%; Wells and Coleman, 1981).

To date, it has been difficult to compare fluid mud properties retrieved from different estuarine systems or other coastal regions because a standardised definition is lacking. Furthermore, fluid mud is often described by only one parameter and is based on single-point measurements. In this study, simultaneous samples were recovered for analyses of SSC, viscosity, mud: sand ratio, grain sizes, POM, temperature, and salinity at closely spaced, vertical intervals across the water-solid bed interface at a number of different sites of two estuaries. On this basis, more parameters than merely SSC and sediment density were available. These were grouped by means of a hierarchical cluster analysis into statistically significant categories, which served to promote a multilayer classification of near-bed, fine, cohesive sediments.

\section{REGIONAL SETTINGS}

The upper mesotidal to lower macrotidal, coastal plain estuaries of the Weser and Ems rivers are located along the southern North Sea coast of Germany (Figures 1a-c). The tidally influenced parts, which extend from the open North Sea to the weir at Bremen, Germany, in the case of the Weser estuary and up to Herbrum, Germany, in the case of the Ems estuary, are about 120 and $100 \mathrm{~km}$ long, respectively (Table 2). Both estuaries are channel-like along the upper river section and funnel-shaped along the lower section. Both river geometries are strongly anthropogenically influenced by repeated deepening, ongoing maintenance, and constructional works in and along the navigation channels. The sustained navigable depth in the channel-like section of the Weser estuary is currently $9 \mathrm{~m}$ at low springs (Schrottke et al., 2006) and $5.7 \mathrm{~m}$ in the Ems estuary (Schuchardt et al., 2007). As a consequence of the man-induced changes in river geometry during the past decades, the tidal range has substantially increased in both estuaries (Table 2). Today the mean tidal range in the Weser estuary varies from $3.6 \mathrm{~m}$ at Bremerhaven, Germany, to $4 \mathrm{~m}$ at Bremen, Germany (Grabemann and Krause, 2001). In the Ems estuary, it currently amounts to $3.8 \mathrm{~m}$ (Jürges and Winkel, 2003).

Both estuaries are characterised by semidiurnal tides but differ in tidal dominance, river runoff, sediment budget, and spatial distribution of fluid mud, despite their geographical proximity (Table 2). The long-term, mean, annual, freshwater discharge amounts to $326 \mathrm{~m}^{3} / \mathrm{s}$ in the Weser estuary and $80 \mathrm{~m}^{3} / \mathrm{s}$ in the Ems estuary (NLWKN, 2009). Average current velocities in the Weser estuary range from 1 to $1.3 \mathrm{~m} / \mathrm{s}$; maximum values of $2.6 \mathrm{~m} / \mathrm{s}$ are achieved during the ebb-tidal phase (Bundesanstalt für Gewässerkunde, 1992). Average current velocities in the Ems estuary are considerably lower, rather site-specific, and variable in dependence on freshwater discharge (Spingat and Oumeraci, 2000). Thus, maximum current velocities around $1 \mathrm{~m} /$ s occur near Herbrum, Germany, only during periods of high freshwater discharge (Spingat and Oumeraci, 2000). Overall, the current velocity decreases slightly downstream because of the widening of the channel cross-section (Spingat and Oumeraci, 2000). Both the Weser and Ems estuaries are 
Table 2. Environmental data from the German Weser and Ems estuaries.

\begin{tabular}{|c|c|c|}
\hline Parameter & Weser & Ems \\
\hline Estuary type & Coastal plain & Coastal plain \\
\hline \multicolumn{3}{|l|}{ Length $(\mathrm{km})$} \\
\hline Total & $477\left({ }^{1}\right)$ & $370\left({ }^{1}\right)$ \\
\hline Tidal influenced part & 〜120 (Intschede, Wadden Sea) & $\sim 100$ (Herbrum, Wadden Sea) \\
\hline \multicolumn{3}{|l|}{ Shape } \\
\hline Upper estuary & channel-like (Bremen, Bremerhaven) & channel-like (Herbrum, Pogum) \\
\hline Lower estuary & funnel-shaped, double channel (Bremerhaven, Wadden Sea) & funnel-shaped (Pogum, Wadden Sea) \\
\hline $\begin{array}{l}\text { Navigation depth for channel like } \\
\text { section at low springs }(\mathrm{m})\end{array}$ & $9(2)$ & $5.7\left({ }^{3}\right)$ \\
\hline Tide & Semidiurnal, ebb-dominated & Semidiurnal, flood-dominated \\
\hline $\begin{array}{l}\text { Range changes }(\mathrm{m}) \\
\text { Mean range }(\mathrm{m})\end{array}$ & $\begin{array}{l}0.13(1882)-4(1990)\left(^{4}\right) \\
\left.\sim 4(\text { Bremen; macrotidal }){ }^{5}\right) \\
\sim 3.6(\text { Bremerhaven; mesotidal })\left({ }^{*} 5\right)\end{array}$ & $\begin{array}{l}2.9(1981)-3.7(1998)\left(^{6}\right) \\
3.8(\text { mesotidal })\left({ }^{6}\right)\end{array}$ \\
\hline Freshwater discharge measured at & Intschede & Versen \\
\hline Mean $\left(\mathrm{MQ} ; \mathrm{m}^{3} / \mathrm{s}\right)$ & $326\left({ }^{7}\right)$ & $80\left({ }^{7}\right)$ \\
\hline Low mean (MLQ; m³ $\left.{ }^{3}\right)$ & $117\left({ }^{7}\right)$ & $16\left({ }^{7}\right)$ \\
\hline High mean $\left(\mathrm{MHQ} ; \mathrm{m}^{3} / \mathrm{s}\right)$ & $1230\left({ }^{7}\right)$ & $373\left({ }^{7}\right)$ \\
\hline \multicolumn{3}{|l|}{ Currents $(\mathrm{m} / \mathrm{s})$} \\
\hline Mean velocity & $1-1.3\left({ }^{3}\right)$ & Location specific \\
\hline Maximum velocity & $2.6\left({ }^{3}\right)$ & $1\left(^{8}\right)$ \\
\hline TMZ & Partially mixed & Partially mixed \\
\hline Length (km) & $15-20(5)$ & $>60\left({ }^{9}\right)$ \\
\hline Location & Around Blexen & Around Gandersum \\
\hline \multicolumn{3}{|l|}{$\mathrm{SSC}$ in TMZ (g/L) } \\
\hline Range & $0.03-1.5\left({ }^{10}\right)$ & up to $1.6\left({ }^{12}\right)$ \\
\hline Mean & $0.13\left(^{(11}\right)$ & $0.9\left({ }^{12}\right)$ \\
\hline Bed morphology & $\begin{array}{l}\text { TMZ: smoothed bed, dredged areas with dredge scours, } \\
\text { subaqueous dunes }\left({ }^{2}\right)\end{array}$ & Lower Ems: tidal flats $\left({ }^{13}\right)$ \\
\hline \multirow[t]{2}{*}{ Bottom material } & TMZ: mud (up to $98 \%$ of total sediment), fine-coarse sand $\left(^{2}\right)$ & $\begin{array}{l}\text { Lower Ems: very fine-fine sand clay } \\
\quad(0.3-3.5 \%)^{(13)} \text { Partly peat }\end{array}$ \\
\hline & $\begin{array}{l}\text { Outside TMZ: fine \& medium sand (silt \& clay }<1 \% \text {, } \\
\quad \text { organic matter }<0.1 \%)\left({ }^{5},{ }^{10}\right)\end{array}$ & \\
\hline \multicolumn{3}{|l|}{ Fluid mud } \\
\hline Distribution & $\begin{array}{l}\text { Extensive areas in the central section of the TMZ; patchy, } \\
\text { in dune troughs throughout the whole TMZ }\end{array}$ & As layer in the whole TMZ \\
\hline Thickness & $\mathrm{cm}$-metres $\left({ }^{2}\right)$ & Up to several metres $\left({ }^{14}\right)$ \\
\hline
\end{tabular}

${ }^{(1)}$ Seedorf and Meyer (1992).

${ }^{(2)}$ Schrottke et al. (2006).

${ }^{(3)}$ Schuchardt et al. (2007).

${ }^{(4)}$ Bundesanstalt für Gewässerkunde (1992).

${ }^{(5)}$ Grabemann and Krause (2001).

${ }^{(6)}$ Jürges and Winkel (2003).

(7) NLWKN (2008).

${ }^{(8)}$ Spingat and Oumeraci (2000).

(9) van de Kreeke, Day, and Mulder (1997).

${ }^{(10)}$ Grabemann and Krause (1989).

${ }^{(11)}$ Schuchardt, Haseloop, and Schirmer (1993).

${ }^{(12)}$ Wurpts and Torn (2005).

${ }^{(13)}$ de Jonge (1988).

${ }^{(14)}$ Schrottke et al. (2007).

partially mixed and exhibit well-developed TMZs extending to the low-salinity reaches located around Blexen, Germany, in the case of the Weser estuary, and around Gandersum, Germany, in the case of the Ems estuary (Figures 1a-c). The TMZ of the Weser estuary extends 15-20 km (Grabemann and Krause, 2001), whereas that of the Ems estuary extends for more than $60 \mathrm{~km}$ (van de Kreeke, Day, and Mulder, 1997). Values of SSC in the water column of the TMZs differ markedly between the estuaries. Thus, in the fairway of the Weser TMZ, the SSC ranges between 0.03 and $1.5 \mathrm{~g} / \mathrm{L}$ (Grabemann and Krause, 2001), with average values of $0.13 \mathrm{~g} / \mathrm{L}$ (Schuchardt, Haseloop and Schirmer, 1993). The Ems TMZ, by contrast, has experienced a dramatic increase in SSC during the past few years (de Jonge, 1983). Whereas a maximum value of $0.4 \mathrm{~g} / \mathrm{L}$ in the water column was measured in 1988 (de Jonge, 1988), the SSC has risen by more than $1 \mathrm{~g} / \mathrm{L}$ in only 12 years (Spingat and Oumeraci, 2000), reaching values up to $1.6 \mathrm{~g} / \mathrm{L} \mathrm{SSC}$ in 2005 (Wurpts and Torn, 2005). 
The riverbed morphology of the Weser TMZ reveals a complex bathymetry comprising stretches of smooth bed, subaqueous dunes of varying size and shape, as well as dredged areas riddled with large dredge scours (Schrottke et al., 2006). Bottom sediments are mainly characterised by mud and fine- to coarsegrained sands, whereas the mud content locally reaches $98 \%$ (Schrottke et al., 2006). Mud deposits are in variable states of consolidation, ranging from very fluid to highly compacted (Schrottke et al., 2006). Organic-rich sediments, such as peat, outcrop at some locations, in particular near the riverbanks (Schrottke et al., 2006). Outside of the Weser TMZ, bottom sediments in the fairway generally consist of fine to medium sand with clay and silt contents $<1 \%$ and POM contents $<0.1 \%$ (Grabemann and Krause, 1989, 2001). In the case of the Ems estuary, most of the information on morphology and sediment composition is limited to the lower estuarine section, where $85 \%$ of the area is covered by tidal flats (de Jonge, 1988). Surface sediments are mainly composed of very fine to fine sand containing abundant peat debris. The clay content varies between 0.3 and $3.5 \%$, increasing toward the shores (de Jonge, 1988).

Fluid mud deposits are regularly observed in both estuaries during slack-water, but they vary with respect to spatial distribution and thickness (Schrottke et al., 2007). In general, fluid mud coverage and thickness is small in the Weser estuary, compared with the Ems estuary, where deposits occur throughout the TMZ and reach thicknesses of up to $6 \mathrm{~m}$ (Schrottke $e t$ al., 2007).

\section{METHODS AND DATA BASE}

This study is based on samplings using a Rumohr-type gravity corer. The mechanism is described in detail in Meischner and Rumohr (1974). Specially designed, transparent Perspex core barrels 2-4 $\mathrm{m}$ in length and $8 \mathrm{~cm}$ in diameter were used for rapid sediment sampling at vertical intervals of $10 \mathrm{~cm}$ (Schrottke et al., 2006). The core barrels were fitted with 2-cmdiameter holes spaced at 10 -cm intervals for sampling. Before deployment, the holes were sealed by tape and consecutively numbered from top to bottom. Depending on the flow regime, weights of 25 to $50 \mathrm{~kg}$ were used for gentle, vertical penetration of the core barrel through the near-bed suspensions and into the riverbed. After recovery, the core was immediately sampled from top downward to avoid sediment settling and consolidation. Depending on sediment density and viscosity, samples were transferred into bottles or bowls by means of polyethylene hoses or syringes. In the case where consecutive core sections had consistently low SSC values, only one large subsample was taken (Schrottke et al., 2006). Immediately on core retrieval, the temperature and salinity of the samples with SSC values below $500 \mathrm{~g} / \mathrm{L}$ were measured using a multimeter of the type Cond $340 \mathrm{i}$ by WTW (Weilheim, Germany). In the laboratory, subsamples were analysed for SSC, POM content, viscosity, and grain-size distribution. The SSC values were recorded as dry weight per unit sample volume. Depending on the sample consistency, an aliquot was prepared for vacuum filtration using a glass fibre filter (pore diameter $1.2 \mu \mathrm{m}$ ) or by taking $2 \mathrm{ml}$ of consolidated sediment. In a next step, the aliquot was dried for about 12 hours at $60^{\circ} \mathrm{C}$. After weighing, the dried samples were analysed for POM content by weight-loss on ignition, leaving only the clastic mineral components (Dean, 1974). This was done by combustion in a muffle furnace at $550^{\circ} \mathrm{C}$ for 2 hours and 6 hours, respectively.

A rotational rheometer of the Haake Rotovisco RV20 (Gebrueder-Haake, Berlin, Germany) equipped with a M5 Searle measuring system was deployed for viscosity measurements. To reduce the risk of wall slippage and to minimize sample and structure disturbance during tool insertion and measurement, a four-bladed vane tool (diameter $=36.0 \mathrm{~mm}$, height $=20.0 \mathrm{~mm}$ ) was used. Assuming a linear shear rate in the gap between the vane tool and the cup, the cup diameter (diameter $=39.0 \mathrm{~mm}$ ) was selected to be slightly larger than the chosen vane. Approximately $24 \mathrm{ml}$ of sample, just enough to cover the vane tool, was used. Before the measuring procedure, the samples were left to adjust to a temperature of about $20^{\circ} \mathrm{C}$ and were then thoroughly shaken for complete dispersal. A controlled shear rate (CSR) test was carried out for the determination of viscosities (Mezger, 2000). For that test, the vane tool was rotated by an electrical motor with a shear rate of $0.548 \mathrm{~s}^{-1}$. To determine flow behaviour, the shear stress was measured for shear rates between 0.07 and $30 \mathrm{~s}^{-1}$. Reproducibility measurements were only carried out above $0.14 \mathrm{~Pa} \cdot \mathrm{s}$ and $20 \mathrm{~g} / \mathrm{L}$ SSC, respectively.

Grain-size analyses were performed using an autonomous settling tube of the MacroGranometer (Neckargemuend, Germany) type (height $=1.8 \mathrm{~m}$; diameter $=0.2 \mathrm{~m}$ ) to analyse grain sizes in a range between 5 and $-2 \varphi$ (Brezina, 1979, 1986). Grain-size classes from 10.75 to $4 \varphi$ were analysed by the x-raybased SediGraph particle analyser (types 5100TM and 5120TM; Micromeritics Instrument, Norcross, Georgia). Both methods include grain characteristics such as particle shape and density as well as fluid density and viscosity (Flemming and Thum, 1978). An undisturbed, individual, particle-settling process was assumed throughout a turbid-free liquid (Syvitski, Asprey, and Clastenburg, 1991). Before analysis, the samples were desalinated and separated in mud and sand fractions by wet sieving. Particulate organic matter was removed by treatment with $35 \%$ hydrogen peroxide. The sand fraction was additionally treated with $25 \%$ hydrochloric acid for the destruction of the carbonate fraction. A representative split of $0.5-1.0 \mathrm{~g}$ was used for analysis in the settling tube. For SediGraph measurements, $4-6 \mathrm{~g}$ of the sample was transferred into a $60-80$-ml sodium pyrophosphate $(0.05 \%)$ sedimentation liquid. Any remaining aggregates were dispersed by ultrasonic treatment in a bath where sample material is simultaneously heated up to a measuring temperature of $36.5^{\circ} \mathrm{C}$.

The data sets were based on five surveys carried out with the research vessel Senckenberg during the periods 27-28 September 2005 (Ems, neap tide 25 July), 20-27 September 2006 (Ems, neap tide 22 September), 13-14 March 2007 (Weser, neap tide 12 March), 13-20 June 2007 (Ems, spring tide 15 June), and 17 July 2007 (Weser, neap tide 14 July). Samplings represent different sites within the TMZs of the Weser and the Ems estuaries (Figures $1 \mathrm{~b}$ and c). Altogether, 26 cores with a total amount of 445 subsamples were analysed.

A hierarchic cluster analysis was used to group similar sedimentological and rheological properties. Squared Euclidean distances among SSC, viscosity, POM, and mud : sand wt\% 
were determined using the centroid-linkage method with the free statistical software $R$ (Version 2.13.0). Grain-size parameters were not considered in the cluster analysis because, in some cases, not enough material was available for grain-size measurements.

One important requirement for comparison of down-core trends is normalization. Core-to-core comparisons concerning sedimentological and rheological parameters were normalized to a single parameter, as shown schematically in Figure 2. Normalization took place by, e.g., sorting parameter B based on parameter A, keeping the descending order of each sampled core section. Parameter similarities, which would not occur without this procedure (Figure 2a), are highlighted after data processing (Figure 2b). It is important to note that processed data no longer indicate the actual retrieval depth but still reflect the sequence number.

\section{RESULTS}

The SSC-normalized, depth-related variations of viscosity, POM, and mud : sand ratio are reflected in comparative plots as shown in Figures 3a-e. The data predominately reflect a downcore increasing SSC, viscosity, and sand wt\% as well as decreasing POM and mud wt\% (Figure 3). The affiliation toward the clusters is represented by different symbols in Figure 3. In all, four clusters with different sedimentological and rheological characteristics were identified with the cluster analysis. Upper and lower limits, as well as median values and upper and lower quartiles, are represented by the box plots in Figure 4.

Cluster one represents less-concentrated, suspended-sediment samples (Figure 4a). These predominately consist of very poorly sorted, polymodal mud ranging from clay to mediumsized silt particles with a prominent peak at $6.5 \varphi$. Samples with $\mathrm{SSC}>100 \mathrm{~g} / \mathrm{L}$ in parts represent small amounts of well to very well sorted, unimodal, very fine sand fractions with a peak at $3.3 \varphi$. Up to $20 \mathrm{wt} \%$ of the sample material was of organic origin. Whereas the POM contents (wt\%) do not correlate with SSC, the absolute POM concentration ( $\mathrm{g} / \mathrm{L}$ ) shows a positive linear correlation, as expressed in Figure 5. With increasing SSC, the viscosity also increases (Figure 6) but in an exponential manner (Weser estuary: viscosity $=\exp (0.013 \times$ SSC) $\times 0.094, R^{2}=0.8, n=33$; Ems estuary: viscosity $=$ $\left.\exp (0.020 \times \mathrm{SSC}) \times 0.091, R^{2}=0.8, n=155\right)$. The degree of dispersion for SSC, viscosity, POM, and mud: sand ratio is quite low, which can be seen by the lower and upper quartiles shown in Figure 4. When log-scaling, the upper SSC-normalized core section reveals a jump in SSC around $10 \mathrm{~g} / \mathrm{L}$ within cluster one (Figure 3a).

The part of the core section dominated by cluster one coincides with a sudden increase in SSC at $200 \mathrm{~g} / \mathrm{L}$, which is underestimated by SSC normalization but is more prominent when data are not SSC normalized, as shown by the example in Figure 7. Below the cluster-one core section follows a section (200-500 g/L SSC) where cluster types one to three exist simultaneously. This section is characterized by very high viscosities (Figure 3c). The data reveal that the material from the Weser estuary is quite different from that from the Ems estuary in viscosity relative to SSC (Figure 3c). Weser estuary

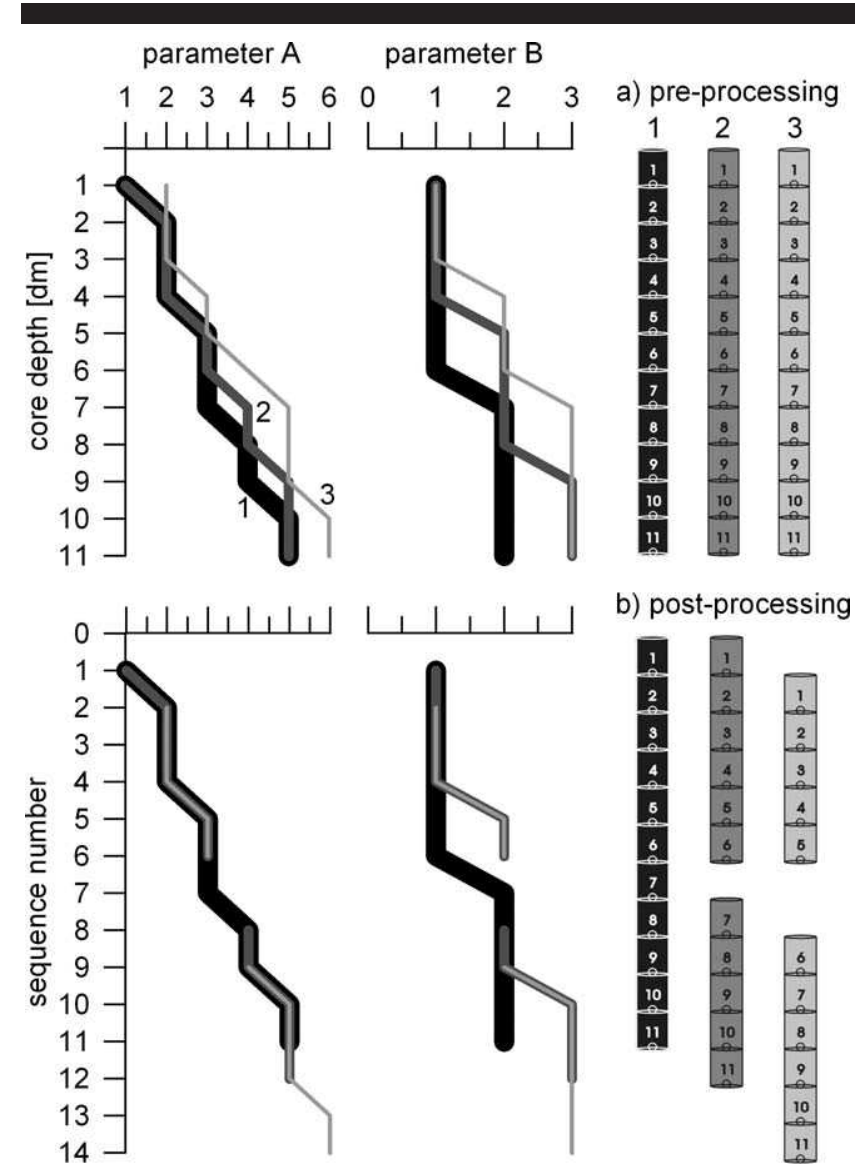

Figure 2. Data processing scheme for normalized parameter comparison. (a) Preprocessing: Parameters A and B of cores 1-3 plotted over depth. No obvious similarities can be identified. (b) Postprocessing: core data normalized to parameter A. Similarities with parameter B are now apparent.

samples are less viscous at corresponding higher SSC values than corresponding samples from the Ems estuary, as expressed by the different exponential fits shown in Figure 6 . Although POM and mud: sand ratios are relatively constant in the section dominated by cluster one $(<200 \mathrm{~g} / \mathrm{L})$, both parameters decrease with increasing SSC in the section between 200 and $500 \mathrm{~g} / \mathrm{L}$ SSC. The change in mud: sand ratio is also reflected in the grain-size distribution (Figure 8). Thus, the mud fraction around $6.5 \varphi$ (medium silt) is slightly diminished, whereas the coarse silt fraction $(5-6 \varphi)$ is enriched. At the same time, the sand fraction has a second subordinate peak around $2.1 \varphi$, at least in the case of the Ems estuary samples. This secondary peak is not present in the sand fractions of the Weser estuary.

Samples with SSCs $>500 \mathrm{~g} / \mathrm{L}$ are dominated by clusters three and four. Typical for these clusters are the missing viscosity data. Rheological measurements were no longer possible on the semisolid samples because friction, caused by high SSCs and sand contents, exceeded the maximum torque of the rheometer. Mud: sand ratios are highly variable in these samples, varying from $80: 20$ to 50:50 wt\% with increasing 


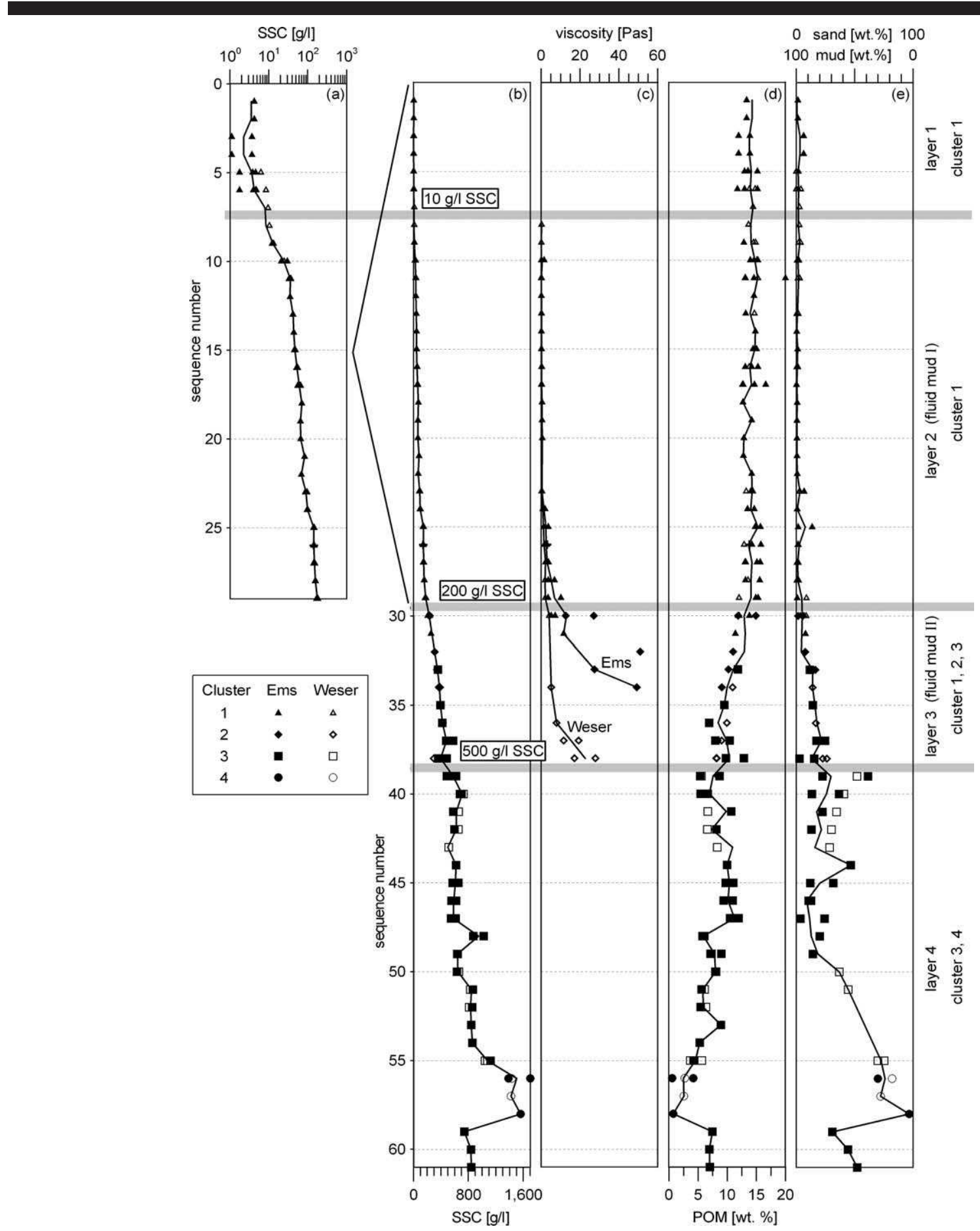

Figure 3. Normalized mean down-core trends in SSC (a, b), and viscosity measured at a shear rate of $0.548 \mathrm{~s}^{-1}$ (c), POM (d), and mud : sand content (e) based on samples from nine cores from the Weser and Ems estuaries. Left box displays SSC values of sequence numbers $<30$ on a logarithmic scale. The three thick horizontal lines highlight marked changes in the boundaries of layers one through four. The symbols represent the cluster affiliation.

SSC. Samples from the lowest part of this core section could even be completely composed of sand. In that case, POM was almost absent. In general, the contribution of finer silt sizes to the mud fractions from this layer increases up to $8 \%$. Fine sand $(2.1 \varphi)$ is also well represented. A third-intermediate population peaks at $2.6 \varphi$. The POM and mud : sand ratio are highly variable.

Salinity, temperature, and flow behaviour were not considered so far. Sample temperatures range between $9.5^{\circ} \mathrm{C}$ and 

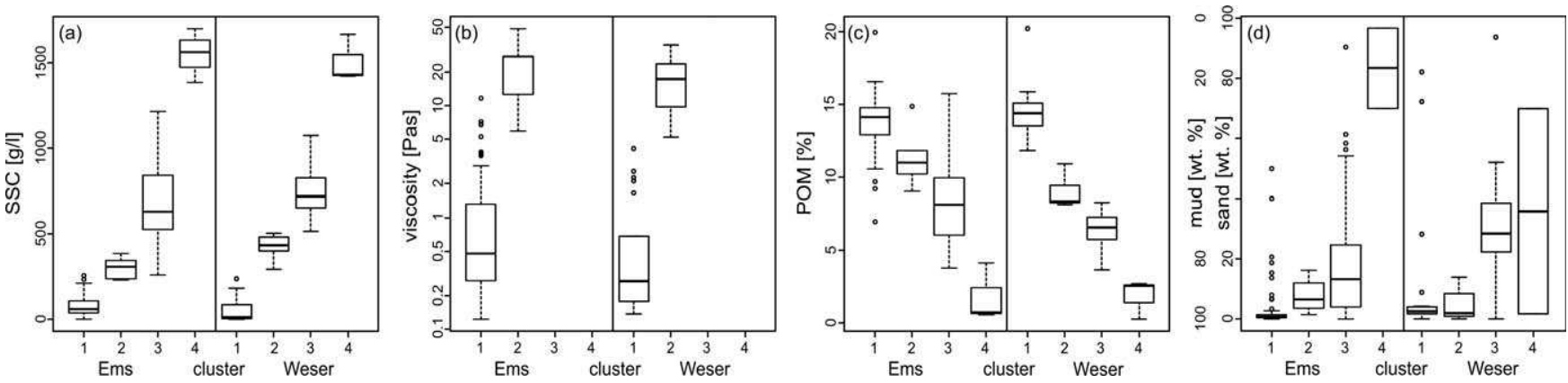

Figure 4. Box plots representing the upper and lower limits, as well as median values and upper and lower quartiles of SSC (a), viscosity measured at a shear rate of $0.548 \mathrm{~s}^{-1}$ (b), POM (c), and mud: sand ratio (d) for clusters one through four of the Weser and Ems estuaries.

$24.1^{\circ} \mathrm{C}$, although there are no systematic depth-related changes recognisable. Temperature differences between the cores reflect seasonal changes. Tide- and lunar-induced temperature variations are not obvious. Salinities ranged between 1 and 7 with no site-specific differences. Generally, salinity decreases downcore. Stratification of near-bed water masses is indicated at some locations. Neither tidal and lunar phases nor seasonal variations are evident in the salinity data.

The flow behaviour is selectively shown in Figure 9 for two samples from the Ems estuary, one having an SSC of $99 \mathrm{~g} / \mathrm{L}$, the other of $258 \mathrm{~g} / \mathrm{L}$. The low-SSC sample shows pseudoplastic behaviour (shear-thinning) for all shear rates, whereas the high-SSC sample indicates different flow behaviours when subjected to changing shear rates. In the latter case, pseudoplastic flow changes to dilatant (shear-thickening) flow at shear rates between $0.22-0.71 \mathrm{~s}^{-1}$ and $0.91-3.29 \mathrm{~s}^{-1}$.

\section{DISCUSSION}

The vertical distribution of SSC varies by up to four orders of magnitude between the top and bottom of cores from the Weser and the Ems estuaries. This is in accordance with the threelayer models often applied to high-energy environments (e.g., Nichols, 1984). However, after SSC normalization and consideration of different sedimentological and rheological properties, down-core trends indicate at least four layers as also identified in the cluster analysis.

The first layer $(<20 \mathrm{~g} / \mathrm{L})$ (Figure 3$)$ is comparable to the highly concentrated, Newtonian sediment suspension defined in three-layered models (e.g., Winterwerp and van Kesteren, 2004). High organic contents and a lack of silt- and sand-sized particles suggest flocculation processes associated with accelerated settling velocities and enhanced settling rates, particularly under slack-water conditions as also observed by Dankers and Winterwerp (2007). The relatively large variance in SSC within this layer is probably related to variable environmental conditions where stress history and flow regime have a significant influence on the process of hindered settling. Under turbulent conditions SSC has to be higher before flocsettling changes from free to hindered settling rates. The interface between layers one and two (Figure 3) represents the upper fluid-mud boundary, which is characterised by a rapid change in concentration between 5 and $20 \mathrm{~g} / \mathrm{L} \mathrm{SSC}$. With the occurrence of steep concentration gradients, the development of a strong shear-flow zone is reported (Mehta, 1991). Whether this also applies to the upper fluid-mud boundary in the Weser and Ems estuaries can not be currently verified because no reliable viscosity data exist for SSCs below $20 \mathrm{~g} / \mathrm{L}$. In the present study, samples with more than $20 \mathrm{~g} / \mathrm{L}$ SSC were defined as fluid mud when they indicated the appropriate flow behaviour during sampling and where viscosity measurements were possible.

The lower fluid mud boundary is set to $500 \mathrm{~g} / \mathrm{L} \mathrm{SSC} \mathrm{because}$ samples with higher SSCs are not applicable for viscosity measurements, which fits well with results of other studies (see Table 1), where this boundary is commonly defined by the concentration at which the shear flow becomes zero (Mehta, 1991; Ross and Mehta, 1989). In addition, the grouping in the cluster analysis changes at this concentration level. The POM contents and mud:sand ratio show high standard deviations and at least one new grain-size population with a peak around $2.1 \varphi$ in the case of the Ems estuary samples.

However, the results of the cluster analysis, the flow behaviour, and the SSC normalisation suggest that two types of fluid mud exist, comprising layers two and three (Figure 3). Layer two identified in this study represents low-viscosity, fluid mud (I) with the exclusive characteristics represented by cluster one samples, whereas layer three represents highviscosity, fluid mud (II) comprising samples of clusters one, two, and three. Furthermore, measurements of shear stress at different shear rates show that the flow behaviour changes with increasing SSC. Thus, the less-concentrated, pseudoplastic, fluid mud sample with $99 \mathrm{~g} / \mathrm{L}$ SSC (Figure 9), representing layer two, consist of fluid-supported particle assemblages, the loose flocculent particle structure of which will already be broken down by low shear rates, as also reported by Faas (1981). In contrast, the more-concentrated, fluid mud sample with $258 \mathrm{~g} / \mathrm{L}$ SSC (Figure 9), representing layer three, seems to be a more grain-supported assemblage, where the shear rate defines the flow behaviour. The anomalous point in this plot can be explained by a viscosity notch, sensu Faas (1981). At low shear rates, the particle structure is broken down, as observed in the case of the less-concentrated sample, but particles subsequently reorient themselves to a parallel alignment with closer packing (Faas, 1981). This causes temporary shear 

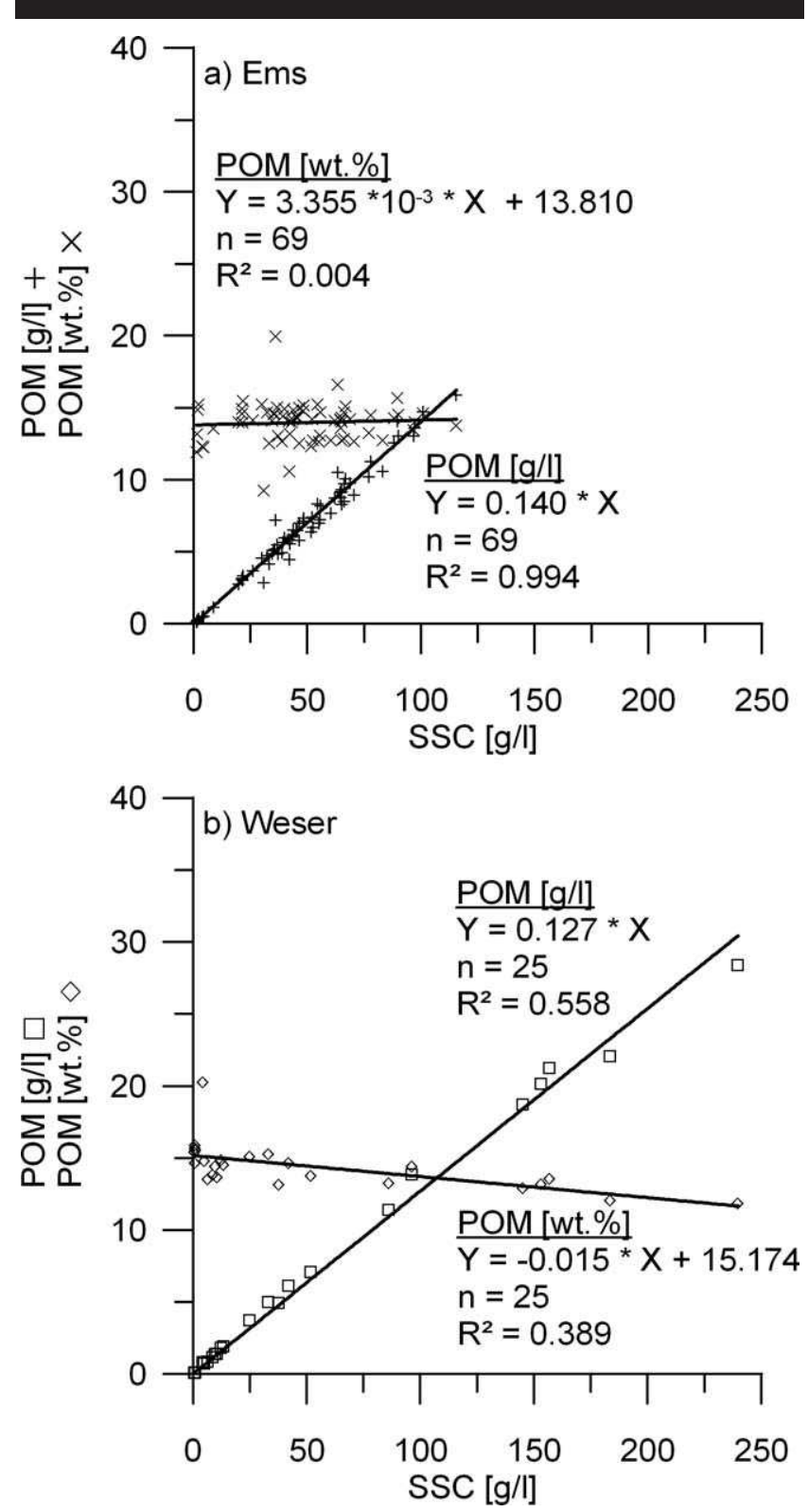

Figure 5. Correlations between POM and SSC for samples of cluster one of the Ems estuary (a) and the Weser estuary (b).

thickening, until the particle structure again breaks down at higher shear rates. However, merely two flow behaviour measurements are not sufficient to accurately determine the precise SSC value at which the flow behaviour of the fluid mud actually changes.

Looking at the viscosity in relation to $\mathrm{SSC}$, a steep increase is apparent around $200 \mathrm{~g} / \mathrm{L} \mathrm{SSC} \mathrm{(Figure} \mathrm{6).} \mathrm{It} \mathrm{can} \mathrm{be} \mathrm{assumed}$ that this increase in viscosity is related to the development of the space-filling concentration at which the suspended sediment begins to build up a network structure, as mentioned by van Maren et al. (2009), thereby, causing the change in flow behaviour. These observations are underpinned by rheological

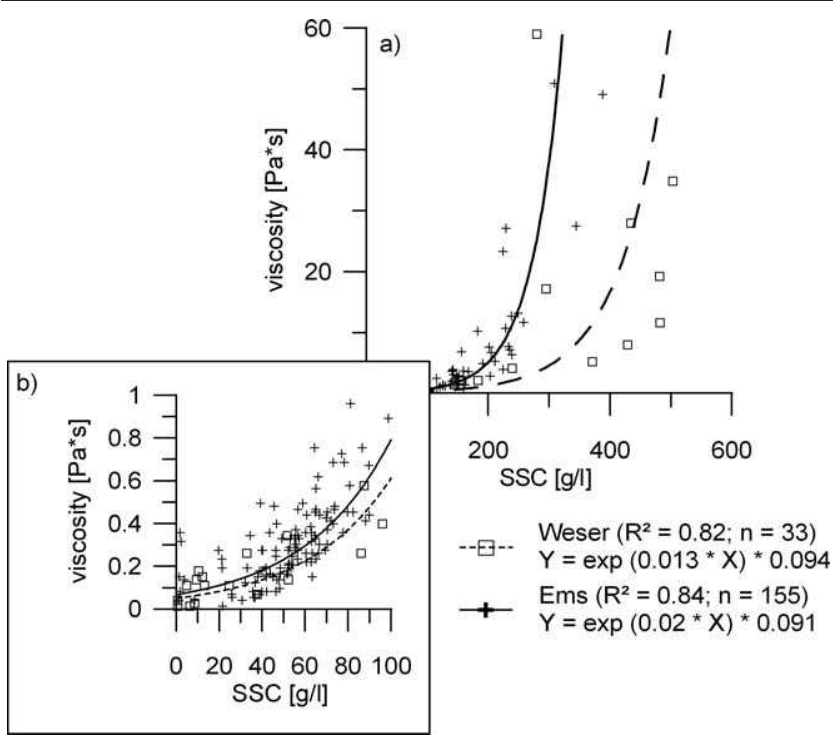

Figure 6. Correlations between viscosity (measured at a shear rate of $0.548 \mathrm{~s}^{-1}$ ) and SSC, based on 33 samples from four cores in the Weser estuary and 155 samples from 23 cores in the Ems estuary. (a) Entire data set; (b) Blowup for the lower SSC range $(<100 \mathrm{~g} / \mathrm{L})$.

investigations on fluid mud carried out on the NE continental shelf of Brazil by Faas (1984). In that study, the changing particle structure is the cause for a change in flow behaviour. However, with a concentration of approximately $100 \mathrm{~g} / \mathrm{L}$, the space-filling concentration on the Brazil shelf is clearly higher than that in the Weser and Ems estuaries. A comparison of the

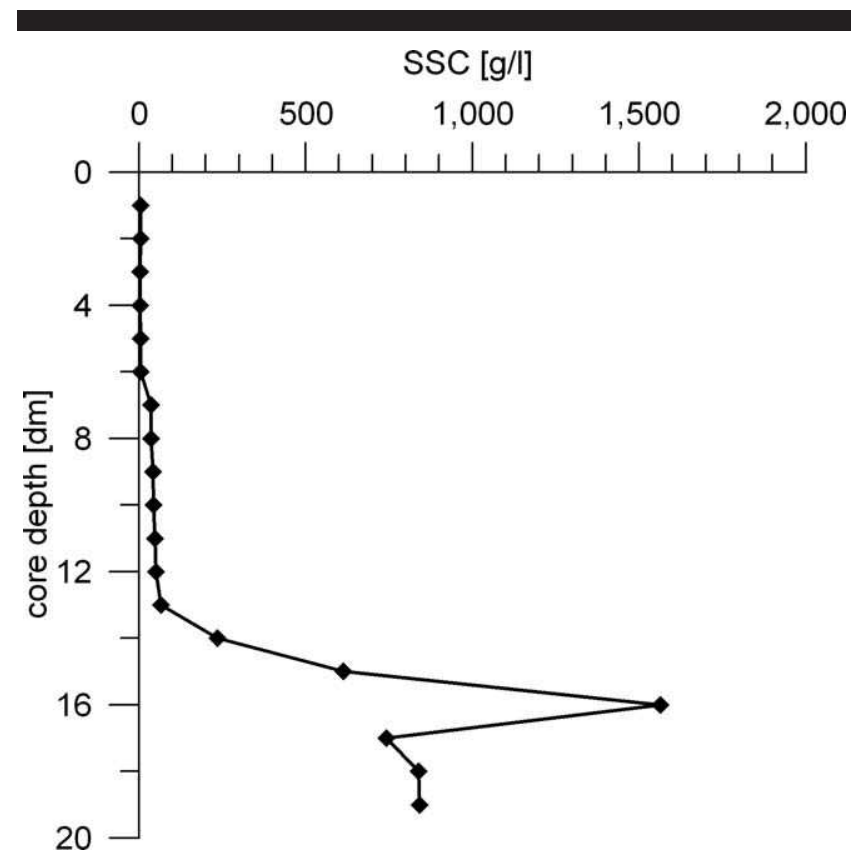

Figure 7. Down-core trend of the SSC of a selected core with a rapid increase in concentration at $200 \mathrm{~g} / \mathrm{L}$. 


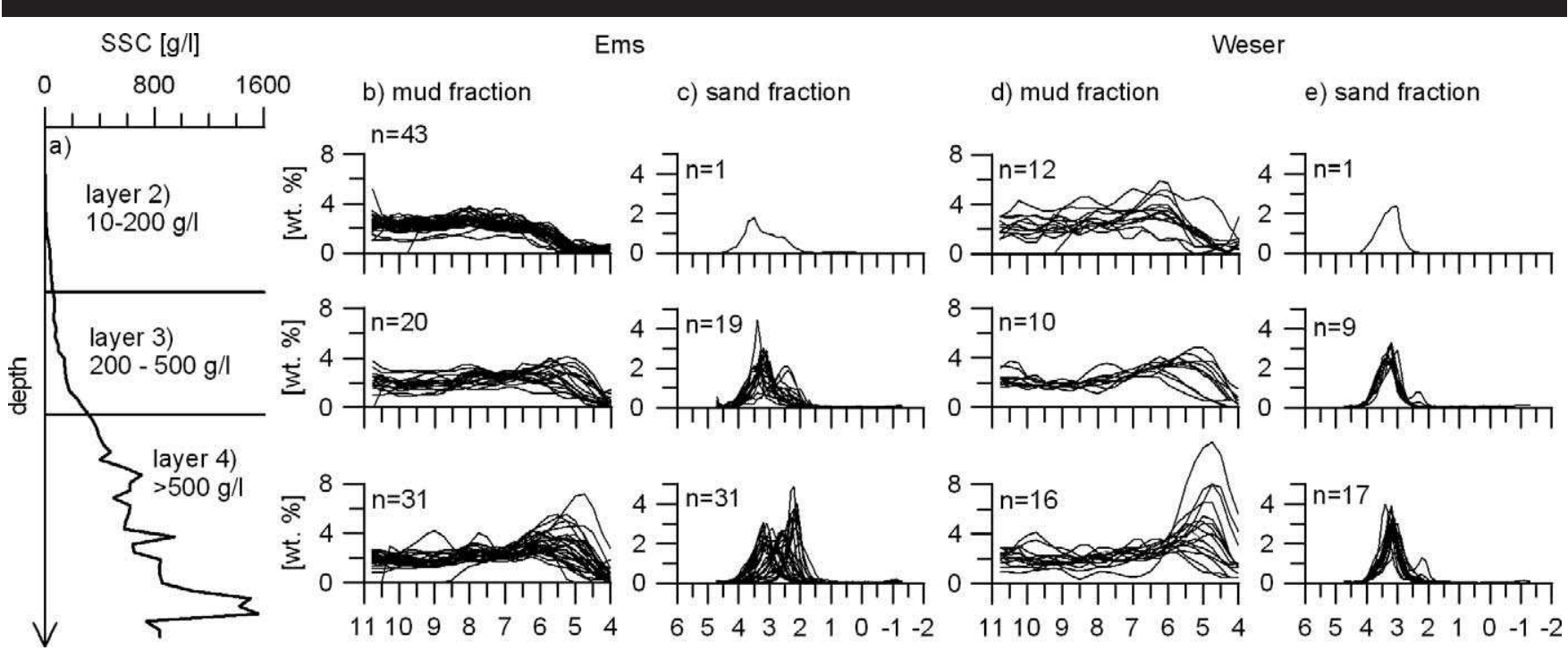

Figure 8. Depth- and SSC-related classification of the estuarine near-bed cohesive sediments (a) and the corresponding grain-size distributions of the mud (b, d) and sand fractions (c, e) of samples from 11 cores from the Weser and Ems estuaries. The SSC curve represents the mean SSC values of the samples from the Weser and Ems estuaries.

two German estuaries reflects highly site-specific viscosity differences. Similar observations are made in the Gironde estuary in France by Granboulan et al. (1989), where viscosity differences at similar SSC values are induced by different sedimentological compositions. Although differences in the grain-size compositions of the suspended sediments from the Weser and Ems estuaries do exist, it cannot be finally ascertained whether grain size is the decisive parameter because the differences are very small. Possible additional factors, which have not been investigated in this study, may be the type of clay that controls the cohesiveness of the material (Mehta, 1989) or the type of POM, which may also influence the internal friction (de Jonge and van den Bergs, 1987).

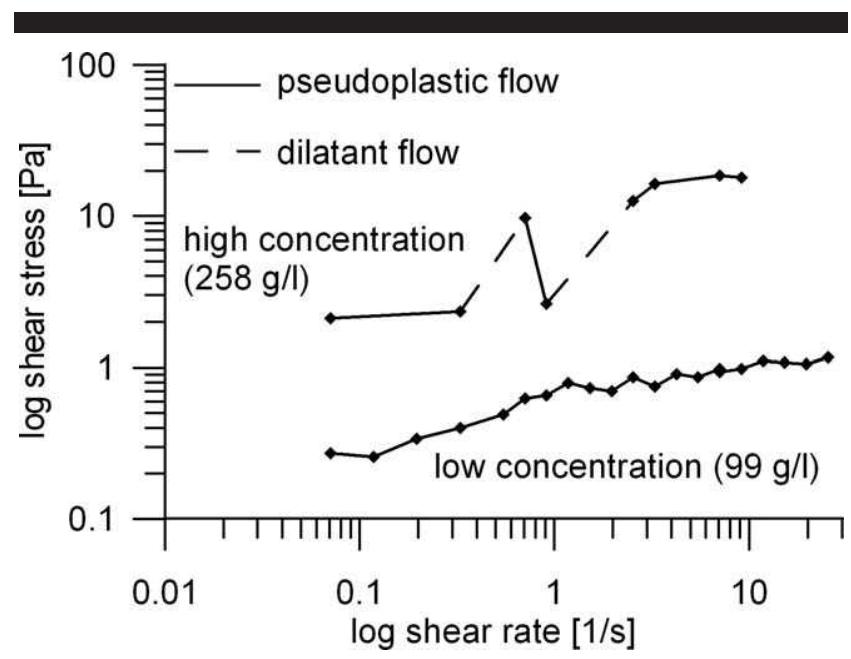

Figure 9. Comparison of flow behaviour of samples having different SSC values of $99 \mathrm{~g} / \mathrm{L}$ (lower curve) and $258 \mathrm{~g} / \mathrm{L}$ (upper curve).
Normalization of SSC measurements and cluster analysis not only reveal the relationship between viscosity and SSC but also a significant SSC dependence on grain size. Because aggregates containing larger particles, such as silt or fine sand, settle out first (Krone, 1993), a gravitationally induced downcore coarsening takes place. An increase in grain-size composition with increasing SSC was also reported in the findings of Kranck et al. (1993). The shifts in grain size, as observed between 5-20 g/L SSC (interface between layers one and two) and $200 \mathrm{~g} / \mathrm{L} \mathrm{SSC} \mathrm{(interface} \mathrm{between} \mathrm{layers} \mathrm{two} \mathrm{and} \mathrm{three),} \mathrm{are}$ related to the lutocline and the space-filling concentration, respectively, where the denser particle-supported framework structure promotes the incorporation of coarser material. This fits with the findings of Manning, Langston, and Jonas (2010), who observed that silt- and sand-sized particles increase the bounding potential of clay and the internal friction. Also, in layer three (200-500 g/L), an increase in internal friction by increased sand content and grain size is responsible for viscosity changes. Particularly at the boundary of layers two and three, this effect is very obvious because a mud: sand ratio up to 50:50 cause excessive grain-to-grain friction and, thereby, prevent viscous behaviour. From Mitchener and Torfs (1996), it is known that a sand: mud ratio of $50 \mathrm{wt} \%$ can raise the erosional shear stress by a factor of two. In addition, internal friction will increase when the effect of lubrication diminishes with decreasing POM content, as shown by Wurpts (2005). Compaction, as a possible cause, can be excluded because samples were remoulded before measurements.

In the present case, it would appear that the low-viscosity fluid mud (I) and the high-viscosity fluid mud (II) have different sources. The composition of fluid mud (I) suggests that the material in that layer originates from the uppermost parts of the highly concentrated suspension of layer one, which has the characteristics defining cluster one. By contrast, fluid mud (II), 
which is characterized by three different clusters, can be generated in two different ways. On the one hand, it could be generated by consolidation of fluid mud (I), on the other, by the resuspension of the upper part of layer four. It can be assumed that the upper part of layer four is still susceptible to erosion, whereas the lower part of layer four represents the consolidated permanent bed, containing silt lenses or even extensive layers of coarser material. It is suggested these structures are generated by different flow regimes related to the neap-spring tidal cycle or seasonal events, such as increased freshwater discharge.

\section{CONCLUSION}

The deployment of a specially adapted Rumohr-type gravity corer enabled the simultaneous sampling of suspended sediment, fluid mud, and the underlying bed of consolidated mud at a higher vertical resolution (10 cm intervals) than in previous studies on fluid mud. On this basis, the comparison between SSC-normalized sedimentological and rheological parameters, supported by a cluster analysis, shows that the conventional three-layer model, as often used to describe vertical, cohesive sediment distributions in high-energy environments, such as estuaries, is evidently incomplete. The present study shows that a low-viscosity and a high-viscosity layer can be distinguished within the fluid mud, provided that in situ measurements are sufficiently resolved vertically. The most important findings of this study can be summarized as follows:

(1) Layer one: Sediment suspensions $<20 \mathrm{~g} / \mathrm{L} \mathrm{SSC}$ of clusterone samples are linked to flocculation processes leading to enhanced, but free-settling, particles in a Newtonian fluid.

(2) Layer two: Low-viscosity fluid mud (I) of 20-200 g/L SSC, is composed of the same cluster of layer one but with fluidsupported particle assemblages that show pseudoplastic flow behaviour caused by the onset of hindered settling.

(3) Layer three: High-viscosity fluid mud (II) of 200-500 g/L SSC occurs where the space-filling concentration is exceeded and the particle framework structure is grain supported. The flow behaviour changes between pseudoplastic and dilatant in dependence on the shear rate. The grouping into clusters one to three indicates the transition from lowviscosity fluid mud to a cohesive or consolidated mud bed.

(4) Layer four: Cohesive or consolidated bed $>500 \mathrm{~g} / \mathrm{L}$ SSC, with characteristics of cluster three and four, evolves from the consolidation of fluid mud containing silt and fine sand, the latter also occurring in the form of layers or lenses representing different flow regimes.

(5) Fluid mud (II) is suggested to represent recurrent, cohesive sediment accumulations, which frequently have to be dredged in harbours and shipping channels to maintain safe navigation depths. Therefore, new approaches to model fluid mud dynamics in greater detail would also serve to optimize dredging activities. Such models should include the two fluid mud layers as outlined in this study.

\section{ACKNOWLEDGMENTS}

The authors would like to thank the captain and crew of the research vessel Senckenberg for their excellent work and inexhaustible patience during the acquisition of the data sets for this study. The assistance of N. Mahnken, A. Raschke, C. Schollenberger, and all their trainees in the laboratories of the Senckenberg Institute, Wilhelmshaven, is also gratefully acknowledged. Furthermore, we wish to thank the working group "Marine Engineering Geology" at the University of Bremen for fruitful discussions and for providing the rotational rheometer. We also thank the reviewers for their helpful critiques and contributions. This study was funded by the Deutsche Forschungsgemeinschaft as part of the Research Centre for Marine Environmental Sciences (MARUM), the Senckenberg Institute who provided the ship time, and the Cluster of Excellence 'The Future Ocean' in Kiel.

\section{LITERATURE CITED}

Brezina, J., 1979. Particle size and settling rate distributions of sandsized materials. PARTEC 79, 2nd European Symposium on Particle Characterisation (Nürnberg), pp. 1-21.

Brezina, J., 1986. Macrogranometer MC86: laboratory manual. Heidelberg, Germany: Granometry, 33p.

Brown, E.; Colling, A.; Park, D.; Phillips, J.; Rothery, D., and Wright, J,. 2006. In: Bearman, G. (ed.), Waves, Tides and Shallow-Water Processes. E. Grinstead, UK: Open University, Milton Keynes, 227p.

Bundesanstalt für Gewässerkunde, 1992. Anpassung der Fahrrine der Außenweser an die künftig weltweit gültigen Anforderungen der Containerschiffe -SKN- 14 m Ausbau (UVU). Koblenz, Germany: Bundesanstalt für Gewässerkunde, 217p.

Dankers, P.J.T. and Winterwerp, J.C., 2007. Hindered settling of mud flocs: theory and validation. Continental Shelf Research, 27, 1893-1907.

Dean, W.E., 1974. Determination of carbonate and organic matter in calcareous sediments and sedimentary rocks by loss on ignition; comparison with other methods. Journal of Sedimentary Research, 44, 242-248.

de Jonge, V., 1983. Relations between annual dredging activities suspended matter concentrations, and the development of the tidal regime in the Ems estuary. Canadian Journal of Fisheries and Aquatic Sciences, 40, 289-300.

de Jonge, V.N., 1988. The Abiotic Environment. In: Baretta, J. and Ruardij, P. (eds.), Tidal Flat Estuaries: Simulation and Analysis of the Ems Estuary-Ecological Studies: Analysis and Synthesis. Berlin: Springer-Verlag, pp. 14-27.

de Jonge, V.N. and van den Bergs, J., 1987. Experiments on the resuspension of estuarine sediments containing benthic diatoms. Estuarine, Coastal and Shelf Science, 24, 725-740.

Faas, R., 1981. Rheological characteristics of Rappahannock Estuary muds, Southeastern Virginia, U.S.A. In: Nio, S.D., Shüttenhelm, R.T.E., and van Weering, Tj.C.E. (eds.), Holocene Marine Sedimentation in the North Sea Basin. Oxford, UK: Blackwell Scientific Publications, SP 5, pp. 505-515.

Faas, R., 1984. Time and density-dependent properties of fluid mud suspensions, NE Brazilian continental shelf. Geo-Marine Letters, 4, 147-152.

Flemming, B.W. and Thum, A.B., 1978. The settling tube - a hydraulic method for grain size analysis of sand. Kieler Meeresforschungen, 4, 82-95.

Grabemann, I. and Krause, G., 1989. Transport processes of suspended matter derived from time series in a tidal estuary. Journal of Geophysical Research, 94, 14373-14379.

Grabemann, I. and Krause, G., 2001. On different time scales of suspended matter dynamics in the Weser estuary. Estuaries and Coasts, 24, 688-698.

Granboulan, J.; Feral, A.; Villerot, M., and Jouanneau, J.M., 1989. Study of the sedimentological and rheological properties of fluid mud in the fluvio-estuarine system of the Gironde estuary. Ocean and Shoreline Management, 12, 23-46.

Herman, P.M.J. and Heip, C.H.R., 1999. Biogeochemistry of the maximum turbidity zone of estuaries (MATURE): some conclusions. Journal of Marine Systems, 22, 89-104. 
Inglis, C.C. and Allen, F.H., 1957. The regime of the Thames estuary as affected by currents, salinities, and river flow. Proceedings of the Institution of Civil Engineers, 7, 827-868.

Jürges, J. and Winkel, N., 2003. Ein Beitrag zur Tidedynamik der Unterems. Mitteilungsblatt der Bundesanstalt für Wasserbau, 86, 29-31.

Kendrick, M.P. and Derbyshire, B.V., 1985. Monitoring of a near-bed turbid layer. Report SR44, Hydraulic Research, Wallingford, U.K.

Kineke, G.C. and Sternberg, R.W., 1995. Distribution of fluid muds on the Amazon continental shelf. Marine Geology, 125, 193-233.

Kirby, R., 1988. High concentration suspension (fluid mud) layers in estuaries. In: Dronkers, J. and van Leussen, W. (eds.), Physical Processes in Estuaries. Berlin: Springer-Verlag, pp. 463-487.

Kranck, K., 1981. Particulate matter grain-size characteristics and flocculation in a partially mixed estuary. Sedimentology, 28, 107114.

Kranck, K.; Petticrew, E.; Milligan, T.G., and Droppo, I.G., 1993. In situ particles distributions resulting from flocculation of suspended sediment. In: Mehta, A.J. (ed.), Nearshore and Estuarine Cohesive Sediment Transport. Washington, DC: American Geophysical Union, Coastal and Estuarine Studies 42, pp. 60-74.

Krone, R., 1962. Flume studies of the transport of sediment in estuarine shoaling processes. Final Report to the San Francisco District U.S. Army Corps of Engineers, Washington, DC.

Krone, R., 1993. Sedimentation revisited. In: Mehta, A.J. (ed.), Nearshore and Estuarine Cohesive Sediment Transport. Washington, DC: American Geophysical Union, Coastal and Estuarine Studies 42, pp. 108-125.

Manning, A.J.; Langston, W.J., and Jonas, P.J.C., 2010. A review of sediment dynamics in the Severn estuary: influence of flocculation. Marine Pollution Bulletin, 61, 37-51.

McAnally, W.H.; Friedrichs, C.; Hamilton, D.; Hayter, E.; Shrestha, P.; Rodriguez, H.; Sheremet, A.; Tester, A., and ASCE Task Committee on Management of Fluid Mud, 2007. Management of fluid mud in estuaries, bays, and lakes. I: present state of understanding on character and behavior. Journal of Hydraulic Engineering, 133, 9-22.

Mehta, A.J., 1989. On estuarine cohesive sediment suspension behavior. Journal of Geophysical Research, 94, 14303-14314.

Mehta, A.J., 1991. Understanding fluid mud in a dynamic environment. Geo-Marine Letters, 11, 113-118.

Meischner, D. and Rumohr, J., 1974. A light-weight, high-momentum gravity corer for subaqueous sediments. Senckenbergiana Maritima, 6, 105-117.

Mezger, T., 2000. Das Rheologie-Handbuch: für Anwender von Rotations- und Oszillations-Rheometer. Hannover: Vincentz Network, 271p.

Mitchell, S.B.; West, J.R.; Johan, C.W., and Cees, K., 2002. Particle size distribution in an estuarine turbidity maximum region. Proceedings in Marine Science, 5, 251-263.

Mitchener, H. and Torfs, H., 1996. Erosion of mud/sand mixtures. Coastal Engineering, 29, 1-25.

Nichols, M., 1984. Fluid mud accumulation processes in an estuary. Geo-Marine Letters, 4, 171-176.

NLWKN (Niedersächsischer Landesbetrieb für Wasserwirtschaft, Küsten- und Naturschutz), 2008. Deutsches Gewässerkundliches Jahrbuch-Weser und Emsgebiet 2005. Norden: NLWKN, 294p.

NLWKN, 2009. Weser- und Emsgebiet 2006. Norden: NLWKN, 294p.

Ross, M.A. and Mehta, A., 1989. On the mechanics of lutoclines and fluid mud. In: Mehta, A. and Hayter, E.J. (ed.), High Concentration Cohesive Sediment Transport, Journal of Coastal Research, Special Issue No. 5, pp. 51-61.

Ross, M.A.; Lin, C.-P., and Mehta, A.J., 1987. On the definition of fluid mud. In: Ragan, R.M. (ed.), Proceedings of the 1987 National Conference on Hydraulic Engineering (New York, New York, ASCE), pp. 231-236.

Schrottke, K.; Bartholomä, A.; Becker, M.; Flemming, B.W., and Hebbeln, D., 2007. Tidally forced dynamics of fluid mud interfaces in tidal estuaries. In: Wefer, G. (ed.), International Conference 2007 and 97th Annual Meeting of the Geologische Vereinigung e.V. (GV) (Bremen), Abstracts 2007/1-2, p. 208.

Schrottke, K.; Becker, M.; Bartholomä, A.; Flemming, B.W., and Hebbeln, D., 2006. Fluid mud dynamics in the Weser estuary turbidity zone tracked by high-resolution side-scan sonar and parametric sub-bottom profiler Geo-Marine Letters, 26, 185-198.

Schuchardt, B.; Haseloop, U., and Schirmer, M., 1993. The tidal freshwater reach of the Weser estuary: riverine or estuarine? Netherlands Journal of Aquatic Ecology, 27, 215-226.

Schuchardt, B.; Scholle, J.; Schulze, S., and Bildstein, T., 2007. Vergleichende Bewertung der Äkologischen Situation der inneren Ästuare von Eider, Elbe, Weser und Ems: Was hat sich nach 20 Jahren verändert? Coastline Reports, 9, 15-26.

Seedorfer, H.H. and Meyer, H.H., 1992. Landeskunde Niedersachsen, Natur, und Kulturgeschichte eines Bundeslandes. Band 1: Historische Grundlage und naturräumliche Ausstattung. Neumünster: Wachholtz Verlag, 517p.

Smith, T.J. and Kirby, R., 1989. Generation, stabilization and dissipation of layered fine sediment suspensions. In: Mehta, A. and Hayter, E.J. (ed.), High Concentration Cohesive Sediment Transport, Journal of Coastal Research, Special Issue No. 5, 63-73.

Spingat, F. and Oumeraci, H., 2000. Schwebstoffdynamik in der Trübungszone des Ems-Ästuars. Die Küste, 62, pp. 159-219.

Sylvester, A.J. and Ware, G.C., 1976. Anaerobiosis of fluid mud. Nature, 264, 635-635.

Syvitski, J.P.M.; Asprey, K.W., and Clattenburg, D.A., 1991. Principles, design and calibration of settling tubes. In: Syvitski, J.P.M. (ed.), Principles, Methods and Application of Particle Size Analysis. New York: Cambridge University Press, pp. 45-63.

Uncles, R.; Stephens, J., and Harris, C., 2006. Properties of suspended sediment in the estuarine turbidity maximum of the highly turbid Humber Estuary system, UK. Ocean Dynamics, 56, 235-247.

Uncles, R.J.; Stephens, J.A., and Law, D.J., 2006. Turbidity maximum in the macrotidal, highly turbid Humber Estuary, UK: Flocs, fluid mud, stationary suspensions and tidal bores. Estuarine, Coastal and Shelf Science, 67, 30-52.

van de Kreeke, J.; Day, C.M., and Mulder, H.P.J., 1997. Tidal variations in suspended sediment concentration in the Ems estuary: origin and resulting sediment flux. Journal of Sea Research, 38, 1-16.

van Leussen, W., 1999. The variability of settling velocities of suspended fine-grained sediment in the Ems estuary. Journal of Sea Research, 41, 109-118.

van Maren, D.S.; Winterwerp, J.C.; Wang, Z.Y., and Pu, Q., 2009. Suspended sediment dynamics and morphodynamics in the Yellow River, China. Sedimentology, 56, 785-806.

Wells, J.T., 1983. Dynamics of coastal fluid muds in low-, moderate and high tide-range environments. Canadian Journal of Fisheries and Aquatic Sciences, 40 (1), 130-142.

Wells, J.T. and Coleman, J.M., 1981. Physical processes and finegrained sediment dynamics, coast of Surinam, South America. Journal of Sedimentary Research, 51, 1053-1068.

Whitehouse, R.; Soulsby, R.; Robersts, W., and Mitchener, H., 2000. Dynamics of Estuarine Muds. London: Thomas Telford, 210p.

Winterwerp, J.C. and van Kesteren, W.G.M., 2004. Introduction to the physics of cohesive sediment in the marine environment. In: T. van Loon (ed.), Developments in Sedimentology 56. Amsterdam: Elsevier, 205p.

Wright and Krone, 1989. Aggregate structure in hyperconcentrated mud flows. Journal of Coastal Research, In: Mehta, A. and Hayter, E.J. (ed.), High Concentration Cohesive Sediment Transport, Journal of Coastal Research, Special Issue No. 5, 117-125.

Wurpts, R., 2005. Hyperconcentrated flow. HANSA International Maritime Journal, 142(09), 75-88.

Wurpts, R. and Torn, P., 2005. 15 Years experience with fluid mud: definition of the nautical bottom with rheological parameters. Terra et Aqua, 99, 22-32. 